\title{
The Effects of Glutamine and N-Acetylcysteine on Experimental Colitis Induced by 2,4,6-Trinitrobenzene Sulphonic Acid in Rats
}

\section{Ratlarda 2,4,6-Trinitrobenzeno Sülfonik Asitle Oluşturulan Deneysel Kolit Üzerine Glutamine ve N-Asetilsisteinin Etkisi}

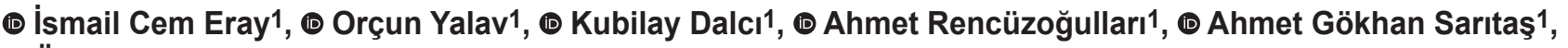

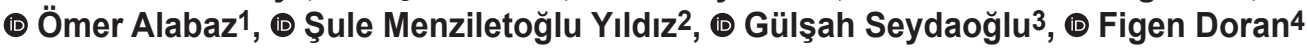

${ }^{1}$ Çukurova University Faculty of Medicine, Department of General Surgery, Adana, Turkey

${ }^{2}$ Çukurova University Faculty of Medicine, Department of Medical Biochemistry, Adana, Turkey

${ }^{3}$ Çukurova University Faculty of Medicine, Department of Biostatistics, Adana, Turkey

${ }^{4}$ Çukurova University Faculty of Medicine, Department of Pathology, Adana, Turkey

\section{HIIIII| ABSTRACT}

\begin{abstract}
Aim: Various factors including free oxygen radicals were have been described in the pathogenesis of inflammatory bowel disease. The aim of this study was to investigate the effects of antioxidant N-acetylcysteine (NAC) and combined glutamine (Gln) on experimental colitis.

Method: In order to achieve this, rats were randomized and administered intraperitoneal NAC or oral Gln + intraperitoneal NAC one day after experimental colitis model induced with trinitrobenzen sulphonic acid. After the treatment, the rats were sacrificed and colon damage was evaluated macroscopically and microscopically. Malonyldialdehyde level and superoxide dismutase activity were analyzed biochemically.

Results: NAC and Gln + NAC groups showed macroscopically better results than the colitis group. Histopathologically, all treated groups provided significantly lower scores than the colitis group. Similarly, all treated groups provided better biochemical results than the colitis group.

Conclusion: According to the results of the experiment, it was concluded that NAC had positive effects on experimental colitis model.

Keywords: Experimental colitis, glutamine, N-acetylcysteine
\end{abstract}

\section{|||||||||| ÖZ}

Amaç: Enflamatuvar barsak hastalığı patogenezinde, serbest oksijen radikallerinin de aralarında bulunduğu çeşitli etkenler tanımlanmıştır. Bu çalışmanın amacı glutamin (Gln) ile kombine edilen antioksidan N-asetilsisteinin (NAC) deneysel kolit modeli üzerindeki etkilerini incelemektir.

Yöntem: Trinitrobenzeno sülfonik asit ile deneysel kolit modeli oluşturulduktan bir gün sonra ratlar randomize edilerek intraperitoneal NAC veya oral Gln + intraperitoneal NAC uygulandı. Tedavi sonrası ratlar sakrifiye edilerek, kolon hasarı makroskobik ve mikroskobik olarak değerlendirildi. Malonil dialdehid seviyesi ve süperoksit dismutaz aktivitesi biyokimyasal olarak analiz edildi.

Bulgular: NAC veya Gln + NAC verilen gruplarda makroskobik olarak kolit grubuna göre daha iyi sonuçlar elde edildi. Histopatolojik olarak tedavi verilen tüm gruplarda kolit grubuna kıyasla anlamlı olarak daha düşük skorlar elde edildi. Biyokimyasal olarakta tedavi verilen tüm gruplarda kolit grubuna kıyasla daha iyi sonuçlar elde edildi.

Sonuç: Deneyden elde edilen sonuçlara göre, NAC uygulanmasının deneysel kolit modeli üzerine olumlu etkili olduğu sonucuna varıldı. Anahtar Kelimeler: Deneysel kolit, glutamin, N-asetilsistein 


\section{Introduction}

Inflammatory bowel disease (IBD) is a systemic disease that involves the gastrointestinal system and affects the quality of life. Although there are a large number of agents currently blamed for the etiology of the disease, it is more widely accepted that the immunoregulation deficiencies of the gastrointestinal tract and oxidative stress are effective and more attention is paid to free oxygen radicals. ${ }^{1}$ In some studies, it was found that the colon biopsies of the patients with IBD had increased free oxygen radicals, and decreased glutathione (GSH) levels and antioxidant enzyme activity in patients with ulcerative colitis. ${ }^{2}$ On the other hand, another study revealed that abnormally low levels of cysteine were measured IBD-related inflammation. ${ }^{3}$

New treatment methods are being searched due to developed tolerance and side effects of the drugs. Trinitrobenzene sulfonic acid (TNBS) is a substance used to create experimental colitis model. ${ }^{4,5,6,7,8}$ In this model, many histopathological and clinical features of Crohn's disease can be observed as in humans and the period of chronic inflammatory response can be extended up to 8 weeks. Ethanol is given to eliminate the barrier of mucous membranes without making any morphological changes in the colon and thus helps the TNBS to penetrate into the intestinal wall. ${ }^{9}$

The purpose of this study was to have a better understanding the role of oxidative stress in the experimental colitis model and examine the effects of NAC and glutamine (Gln) in order to develop other treatment methods. Tissue damage was evaluated macroscopically and microscopically. Superoxide dismutase (SOD) activity and malonildialdehyde (MDA) levels were measured for the evaluation of antioxidant capacity.

\section{Materials and Methods}

The protocol was approved by the Committee of Animal Care and Use, Faculty of Medicine, Çukurova University. In this study, 50 male Wistar albino rats weighing between 220 and $320 \mathrm{gr}$ and and with a mean age of 4 months were used. Light-dark cycle (12 h-12 h) was used during the experiment, and rats were placed in individual cages and were kept at room temperature at about $21^{\circ} \mathrm{C}$. During the study, the rats were fed with distilled tap water and standard pellet feed, and the groups receiving glutamine were fed with $1 \mathrm{~g} / \mathrm{kg}$ of Gln mixed with distilled tap water and standard pellet. Anesthesia in rats was achieved by injecting $50 \mathrm{mg} /$ $\mathrm{kg}$ dose of intramuscular ketamine hydrochloride (Ketalar, Parke Davis and Eczacibaşı, İstanbul) $+5 \mathrm{mg} / \mathrm{kg}$ of xylazine hydrochloride.

\section{The Induction of Colitis}

To create an experimental colitis, a mixture of $30 \mathrm{mg}$ (80 $\mathrm{mg} / \mathrm{kg}$ ) TNBS (92823, picrylsulfonic acid solution $10 \mathrm{~mL}$, purum, Switzerland) $+30 \%$ ethanol was used. According to this method, 8-F polyurethane cannula was placed 8 $\mathrm{cm}$ rectally in anesthetized rats. Colitis was induced by administering $80 \mathrm{mg} / \mathrm{kg}$ TNBS $+0.3 \mathrm{~mL}$ of $30 \%$ ethanol slowly through this cannula. The TNBS-E that remained in the cannula was introduced into the rectum by $1 \mathrm{cc}$ air. Then, rats were held upsidedown for 30 seconds in order to prevent the reflux of the substance given and they were kept in the Trendelenburg position until they awakened from anesthesia.

\section{Experimental Groups and Treatments (Table 1)}

Group I (control group; $\mathbf{n = 1 0 ) : ~ E n e m a ~ w a s ~ a p p l i e d ~ w i t h ~}$ normal saline to the normal rats on the first and second days. Intraperitoneal sulforaphane (SF) was administered between the first and fourth days.

Group II (ethanol group; $\mathbf{n = 1 0}$ ): To monitor the possible effect of ethanol on the intestinal mucosa, $0.3 \mathrm{~mL} 30 \%$ ethanol was given through the anal canal in the supin position to a depth of about $8 \mathrm{~cm}$ through a thin nutrition catheter. The following day, intraperitoneal SF was given between the first and fourth days.

Group III (colitis group; $\mathbf{n}=10$ ): A mixture of $80 \mathrm{mg} / \mathrm{kg}$ TNBS and $1 \mathrm{~mL} / \mathrm{kg} 30 \%$ ethanol was given to a depth of about $8 \mathrm{~cm}$ through a thin nutrition catheter. The following day, intraperitoneal SF was given between the first and fourth days after the operation.

Group IV (NAC; $\mathbf{n = 1 0 ) : ~ A ~ m i x t u r e ~ o f ~} 80 \mathrm{mg} / \mathrm{kg}$ TNBS and $1 \mathrm{~mL} / \mathrm{kg} 30 \%$ ethanol was given to a depth of about $8 \mathrm{~cm}$ through a thin nutrition catheter. The following day, 300 $\mathrm{mg} / \mathrm{kg}$ intraperitoneal NAC injection was performed for 4 days.

Group V (Gln-NAC; $\mathbf{n = 1 0 ) : ~ T w o ~ w e e k s ~ b e f o r e ~ t h e ~ i n d u c t i o n ~}$ of colitis, $10 \mathrm{~g} / \mathrm{L}$ Gln was mixed with drinking water. Drinking water was changed every three days and shaken two times a day. The remaining water was subtracted from the first amount and it was checked if the rats had taken enough water or not. Starting from the day after the induction of

Table 1. Comparison of macroscopical damage scores of the groups (Mann-Whitney U test p value) $(\mathrm{p}<0.05)$

$\begin{array}{lllll}\text { Groups } & \text { Control } & \text { Ethanol } & \text { Colitis } & \text { NAC } \\ \text { Ethanol } & 0.635 & & & \\ \text { Colitis } & 0.001 & 0.001 & & \\ \text { NAC } & 0.001 & 0.001 & 0.023 & \\ \text { Gln-NAC } & 0.001 & 0.005 & 0.001 & 0.001\end{array}$

Gln: Glutamine, NAC: Antioxidant N-acetylcysteine 
colitis, $300 \mathrm{mg} / \mathrm{kg}$ intraperitoneal NAC was injected for 4 days. The rats continued to receive Gln together with the drinking water until sacrificed.

The rats were sacrified on the $14^{\text {th }}$ day after saline enema administration or TNBS-instillation and the distal colon was totally removed.

\section{The Evaluation of Colonic Damage}

\section{Macroscopic Evaluation of the Colon}

After the distal colon was removed under anesthesia by median laparotomy, it was opened longitudinally from the antimesenteric side of colon and the content of the colon was cleared with saline. Wallace macroscopic damage scale was used by a pathologist blinded to the content of the research. ${ }^{10}$

\section{Histopathological Evaluation of the Colon (Table 2)}

Colon tissue samples fixed in $10 \%$ formaldehyde solution were divided into $0.5 \mathrm{~cm}$ pieces. Then, after the standard labarotory follow-up, 5-micron sections were prepared by embedding into paraffine for histopathological examinations and sections were stained with hematoxylin-eosin. They were evaluated by using Olympus CX41 light microscope. The histopathological examinations of the tissues were performed by a pathologist blinded to sample groups using a scale that was mentioned in the previous studies. ${ }^{11,12}$

\section{Measurement of SOD}

Xanthine and xanthine oxidase (XOD) were used to generate superoxide anion radicals that react with 2-(4-iodophenyl)-3(4-nitrophenol)-5-phenyltetrazolium chloride quantitatively to form a red formazan dye. SOD inhibits the reaction by converting the superoxide radical to oxygen. The measurement of SOD enzyme activity is performed with the $\%$ of formazan dye formation at $505 \mathrm{~nm} .^{13,14}$

\section{Measurement of MDA}

Under aerobic conditions, MDA reacts with thiobarbituric acid (TBA) at $95^{\circ} \mathrm{C}$ and $\mathrm{pH} 3.4$ and forms a pink complex. This adduct is measured by spectrophotometer at $532 \mathrm{~nm}$ and expressed as nanomoles/milligrams. ${ }^{15}$

\section{Statistical Analysis}

Normality was checked for each continuous variable. Since the data were not distributed normally, appropriate non-parametric test was chosen. Comparisons between groups were performed using Student's t-test for normally distributed data and Mann-Whitney U test for non-normally distributed data. Bonferroni's correction was applied ( $\mathrm{p}<0.05 / \mathrm{n}$; where $\mathrm{n}=$ number of comparisons) when multiple comparisons were made. The results were presented as mean \pm SD and median (minimum-maximum). Statistical analysis was performed using SPSS v 19.0 statistical package.

\section{Results}

\section{Macroscopic Findings (Table 1)}

\section{Control Group}

No change was detected in the colon macroscopically. The macroscopic damage score was 0 .

\section{Ethanol Group}

The macroscopic damage score was 0 . There was no statistically significant difference between the control group and the ethanol group $(\mathrm{p}=0.635)$. There was a statistically significant difference when compared with the colitis group $(p=0.001)$. Statistically significant differences were found between the ethanol group and NAC group and Gln-NAC group ( $\mathrm{p}=0.001, \mathrm{p}=0.001$ and $\mathrm{p}=0.005$, respectively).

\section{Colitis Group}

The mean macroscopic damage score was 5 . The score was significantly higher when compared with the control group $(\mathrm{p}<0.05)$.

\section{NAC Group}

The mean macroscopic damage score was 3.5. A higher macroscopic damage score was found in the NAC group compared to the control group $(\mathrm{p}<0.05)$. On the other hand, a lower macroscopic score was measured than the colitis group $(\mathrm{p}<0.023)$. When two groups receiving Gln were compared, it was seen that damage score was higher $(\mathrm{p}<0.05)$.

\section{GIn-NAC Group}

The mean macroscopic damage score was 4.5. Higher scores were measured compared to the control group $(\mathrm{p}<0.05)$, whereas the scores were lower than the colitis group $(\mathrm{p}<0.05)$. Macroscopic scores were lower compared to the NAC administered groups ( $\mathrm{p}<0.05)$.

\section{Histopathological Findings (Table 2, Figure 1) \\ Control Group}

The score was 0 in the histopathological evaluation of the control group.

\section{Ethanol Group}

The mean damage score was 0 . There was no statistically significant difference compared to the control group $(\mathrm{p}=0.635)$. The score was significantly lower compared with the TNBS-E administered groups ( $\mathrm{p}<0.05$ for all).

\section{Colitis Group}

The highest damage score was measured in this group (median: 6). This value was higher than all treated groups $(\mathrm{p}<0.05)$. 
Table 2. Comparison of histological damage scores of the groups (Mann-Whitney U test $\mathrm{p}$ value) $(\mathrm{p}<0.05)$

$\begin{array}{lllll}\text { Groups } & \text { Control } & \text { Ethanol } & \text { Colitis } & \text { NAC } \\ \text { Ethanol } & 0.635 & & & \\ \text { Colitis } & 0.001 & 0.001 & & \\ \text { NAC } & 0.001 & 0.001 & 0.004 & \\ \text { Gln-NAC } & 0.001 & 0.046 & 0.001 & 0.001\end{array}$

Gln: Glutamine, NAC: Antioxidant N-acetylcysteine
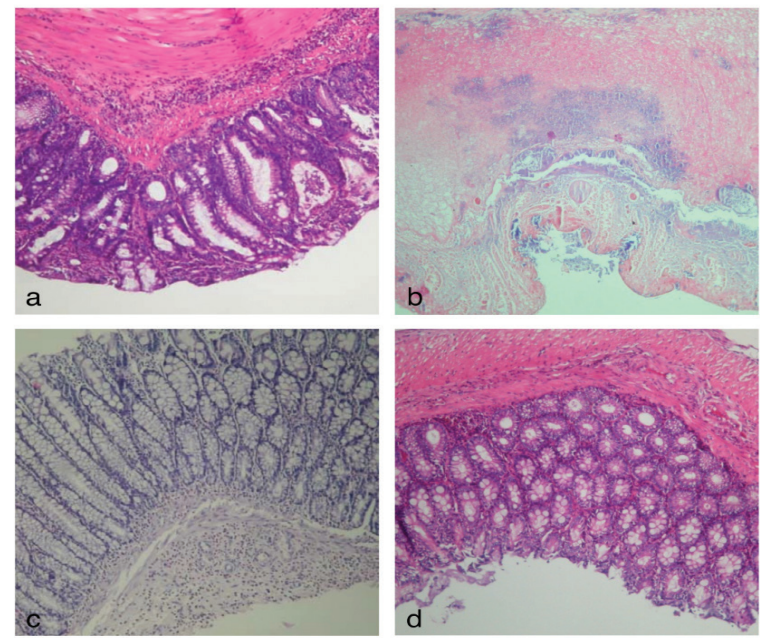

Figure 1. Histopathologic appearances of colon specimens: (a) Control group; normal colonic tissue HE x100, (b) Colitis group (TNBS); fullthickness colon necrosis (HE x40), (c) NAC group (TNBS + NAC); mild chronical inflammation (HE x100), (d) Gln-NAC group (TNBS + GlnNAC); mild inflammation and edema (HE $\times 40)$

HE: Hematoxylin eosin, TNBS: Trinitrobenzene sulfonic acid, NAC: Antioxidant N-acetylcysteine, Gln: Glutamine

Distribution of values of SOD according to groups

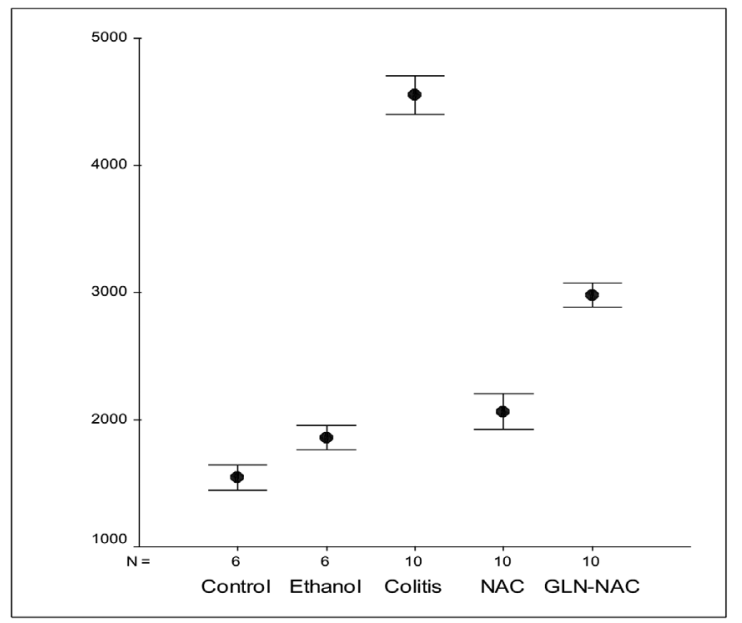

Figure 2. Mean and 95\% CI of SOD according to the study groups SOD: Superoxide dismutase, CI: Confidence interval, NAC: Antioxidant N-acetylcysteine, Gln: Glutamine

\section{NAC Group}

When compared to with the control and ethanol groups, higher histopathological damage scores were measured (median: 2, $\mathrm{p}<0.05$ ). The score was lower than the colitis group $(\mathrm{p}<0.05)$.

\section{GIn-NAC Group}

A slightly higher histopathological damage score was measured than the control and ethanol groups (median: 1, $\mathrm{p}<0.05)$. The damage scores were lower in this group than the colitis and NAC groups $(\mathrm{p}<0.05)$.

\section{The Results of SOD Activitiy Measurement (Figure 2)}

\section{Ethanol Group}

A statistically significant increase in SOD activity was observed in this group compared to the control group $(\mathrm{p}=0.007)$. While there was no statistically significant difference between ethanol group and NAC group, a lower SOD activity was measured in the ethanol group compared with the TNBS-E administered groups $(\mathrm{p}=0.224)$.

\section{Colitis Group}

The highest SOD activity was measured in this group. The SOD activity was lower in the treated groups than in the colitis group.

\section{NAC Group}

A higher SOD activity was detected compared to the control group $(\mathrm{p}<0.017)$. The lowest SOD acvitity was measured in the NAC group among the treated groups.

\section{GLN-NAC Group}

The results in this group were higher than NAC group ( $\mathrm{p}=0.001)$.

\section{The Results of MDA Measurement (Figure 3)}

\section{Ethanol Group}

The values in the ethanol group were higher than in the control group $(\mathrm{p}=0.01)$. The values were lowest when compared to all TNBS-E administered groups.

\section{Colitis Group}

The highest MDA level was obtained in this group. The values were found to be statistically higher than the treated groups.

\section{NAC Group}

Similar with SOD activity, the lowest MDA level was obtained in this group. No statistically significant difference was found between this group and ethanol group ( $\mathrm{p}=0.201)$.

\section{GIn-NAC Group}

MDA levels in this group were higher than the control group ( $\mathrm{p}=0.001)$. When compared to the colitis group, MDA levels were found to be statistically and significantly decreased $(\mathrm{p}=0.001)$. 
Distribution of values of MDA levels according to groups

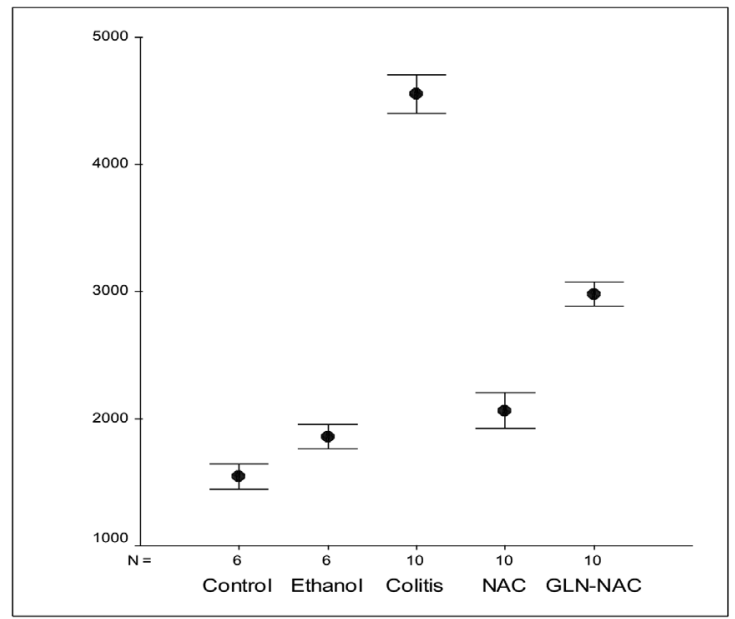

Figure 3. Mean and 95\% CI of MDA according to the study groups

MDA: Malonildialdehyde, CI: Confidence interval, NAC: Antioxidant N-acetylcysteine, Gln: Glutamine

\section{Discussion}

Today, there is no definitive treatment for IBD except for surgery. Many clinical and experimental studies are performed to establish new treatment protocols. Oxidative stress is believed to play a key role in the pathogenesis of mucosal damage of IBD. In some of these studies, antioxidant substances have been investigated. In our study, we investigated the effect of NAC on oxidative stress and morphological changes in IBD, and the possible synergistic interaction of adding Gln, which is one of the precursors of GSH and an important antioxidant, such as cysteine in the composition of NAC.

In this study, colitis was induced with TNBS-E as shown in the literature. Expected findings were obtained in all groups with administered TNBS-E in compliance with the expected results and damage scores in all groups were higher than the control group. Unlike other studies, the efficacy of ethanol was evaluated as a given mucosal barrier breaker. The results showed that ethanol did not cause morphological damage, however, it increased SOD activity and MDA levels. Some studies evaluating the effect of ethonal on other systems have reported that altered MDA and SOD activities. ${ }^{16,17,18,19}$ We think that ethanol in the TNBS-induced colitis model increased the SOD activity and MDA levels and it may affect the evaluation of the results obtained.

The effect of NAC on experimental colitis model has been investigated by many researchers. Siddiqui et al., ${ }^{20}$ investigated the effect of NAC, meselamine and NAC + mesalamine on mucosal recovery in TNBS-E-induced colitis model. It was showed that mesalamine + NAC reduced colonic inflammation and ulceration, and provided some curative effects on mucosa compared to their individual use. Besides, it was reported that combined treatment resulted in significant myeloperoxidase activitiy inhibition. ${ }^{20}$ In another study conducted on a group of people, NAC and mesalamine were administered to some patients, and mesalamine and placebo were administered to another group. Consequently, better clinical results were observed with decrease of chemokines in the mesalamine and NAC group. ${ }^{21}$ As noted in other studies, lower scores were obtained macroscopically and histopathologically in the damaged colon mucosa compared to the colitis model upon the application of NAC $(\mathrm{p}<0.05)$. The macroscopic and histopathological results obtained by adding Gln to NAC were better.

Free oxygen radicals form lipid peroxide radicals by causing lipid peroxidation. The resulting lipid peroxide radicals play an important role in the formation of the inflammatory process. Antioxidants are protective compounds against the harmful effects of free oxygen radicas. One of the most important enzymatic antioxidants is SOD. These enzymes are part of the natural defense system. The increased MDA levels in tissues reflect the level of lipid peroxidation. ${ }^{22}$ Kurutas et al., ${ }^{23}$ found that NAC treatment protects the organism from the noxious substances of lipid peroxidation in acetic acid-induced colitis models. In our study, MDA levels were measured lower with NAC application compared to the colitis model. On the other hand, it was statistically significantly higher compared to the NAC group.

Two cytoplasmic enzymes, SOD and myeloperoxidase, protect the cell from oxidizing agents by breaking down superoxide anions and hydrogen peroxide. SOD reduces the oxidative stress and inflammatory response mediators. ${ }^{24}$ SOD acts as an important preservative to prevent the damaging effects of superoxide anion radicals. Kuralay et al., ${ }^{25}$ showed that SOD levels increased in response to oxidative stress in the experimental colitis model and that this increase was reduced by antioxidant agents. Kruidenier et al. ${ }^{26}$ demonstrated that $\mathrm{Cu} / \mathrm{Zn}$ SOD and MnSOD levels of the colonic mucosa in patients with IBD were higher than the control group. In this study, we observed lower SOD levels in the NAC group than in the colitis group. Similar with the other studies, it was concluded in our study that the antioxidant application had a positive effect on the colitis model in terms of treatment. Compared to the colitis model, a greater reduction was observed in the SOD level in the NAC + Gln group. However, contrary to expectations, the addition of Gln to NAC treatment did not provide more positive results. One reason for this is that Gln was mixed with drinking water and it might not reach enough tissue concentration. 


\section{Conclusion}

In conclusion, TNBS-E-induced colitis model is easy to perform, but ethanol affects SOD activity and MDA levels. The administration of NAC appears to have beneficial effects on TNBS-E induced colitis, as indicated by decreased expression of SOD activity and MDA levels and by the scores that were used in the morphological evaluation.

\section{Ethics}

Ethics Committee Approval: The study was approved by the Çukurova University Animal Experiments Local Ethics Committee (approval number: 22.12.2016/11)

Informed Consent: Experimental animal study.

Peer-reviewed: Externally peer-reviewed.

\section{Authorship Contributions}

Surgical and Medical Practice: İ.C.E., A.R., K.D., A.G.S., Consept: O.A., İ.C.E., Design: İ.C.E., O.Y., S.M., Data Collection or Processing: İ.C.E., F.D., G.S., Analysis or Interpretation: G.S., İ.C.E., A.R., Literature Search: K.D., O.Y., A.G.S., İ.C.E., Writing: İ.C.E., A.R.

Conflict of Interest: No conflict of interest was declared by the authors.

Financial Disclosure: The authors declared that this study received no financial support.

\section{References}

1. Balmus IM, Ciobica A, Stanciu C. The implications of oxidative stress and antioxidant therapies in inflammatory bowel disease: clinical aspects and animal models. The Saudi J Gastroenterol 2016;22:3-17.

2. Nieto N, Torres MI, Fernandez MI, Giron MD, Rios A, Suarez MD, et al. Experimental ulcerative colitis impairs antioxidant defense system in rat intestine. Digestive diseases and sciences 2000;45:1820-1827.

3. Sido B, Hack V, Hochlehnert A, Lipps H, Herfarth C, Dröge W. Impairment of intestinal glutathione synthesis in patients with inflammatory bowel disease. Gut 1998;42:485-492

4. Koksal HM, Erturk AD, Celayir MF, Ylldırm S, Oner M, Baykan A. The Effects of Enoxaparine on Anastomoic Healing in Rats with Chemical Induced Inflammatory Bowel Disease. Turk J of Colorectal 2009;19:14-23.

5. Kara E, Sakarya A, Var A, Vatansever S. The effect of low-dose methotrexate on endothelial dysfunction and programmed cell death (apoptosis) in 2,4,6 trinitrobenzesulphonic acic (tnbsa)- induced model of experimental colitis. Turk J Colorectal 2010;20:66-75

6. Wengrower D, Liakim R, Karmeli F, Razin E, Rachmilewitz D. Pathogenesis of ulcerative colitis (UC): enhanced colonic formation of inositol phosphates (IP) and platelet activatingfactor (PAF). Gastroenterology 92:169-198.

7. Güllüoğlu BM, Kurtel H, Güllüoğlu MG, Aktan AO, Yeğen C, Dizdaroğlu F, et al. Bombesin Ameliorate s Colonic Damage in Experimental Colitis. Dig Dis Sci 1999;44:1531-1538.

8. Gultekin FA, Emre AU, Celik SK, Barut F, Tali U, Sumer D, et al. Effects of Humanin on Experimental Colitis Induced by 2,4,6- trinitrobenzene Sulphonic Acid in Rats. Saudi J Gastroenterol 2017;23:105-111.
9. Keshavarzian A, Kanofsky JR, Ibrahim CM, Doria MI: Excessive generation of reactive oxygen metabolites by colonic mucosa in experimental colitis: Analysis using chemiluminiscence probe. FASEB J 1990;4:761.

10. Wallace JL, MacNaughton WK, Morris GP, Beck PL. Inhibition of leukotriene synthesis markedly accelerates healing in a rat model of inflammatory bowel disease. Gastroenterology 1989;96:29-36.

11. Morris GP, Beck PL, Herridge MS, Depew WT, Szewczuk MR, Wallace RL. Hapten-induced model of chronic inflammation and ulceration in the rat colon. Gastroenterology 1989;96:795-803.

12. Mei Q, Yu J-P, Xu J-M, Wei W, Xiang L, Yue L. Melatonin reduces colon immunological injury in rats by regulating activity of macrophages. Acta Pharmacologica Sinica 2002;23:882-886

13. Fridovich I. Superoxide Radicals and Superoxide Dismutases. Annu Rev Biochem 1995;64:97-112

14. Lowry OH, Rosebrough NJ, Farr AL, Randall RJ. Protein Measurement with the Folin Phenol Reagent. J Biol Chem 1951;193:265-275.

15. Ohkawa H, Ohishi N, Tagi K. Assay for lipit peroxides in animal tissues by Thiobarbituric acid reaction. Anal Biochem 1979;95:351-358.

16. Akkuş I, Gültekin F, Aköz M, Cağlayan O, Bahçaci S, Can UG,et al. Effect of moderate alcohol intake on lipid peroxidation in plasma, erythrocyte and leukocyte and on some antioxidant enzymes. Clin Chim Acta 1997:266:141-147.

17. Punchard NA, Senturk H, Teare JP, Thompson RP. Resistance of erythrocytes to lipid peroxidation in alcoholic patients. Gut 1994;35:17531756.

18. Dudek IM, Kedziora J, Zagorski T. Effect of ethanol on human erythrocyte superoxide dismutase activity and malonyl dialdehyde concentration. Int J Occup Med Environ Health 1995;8:239-243.

19. Armutcu F, Gurel A, Sogut S, Aksu N, Unalacak M. Levels of erythrocyte oxidant and antioxidant parameters in people with alcohol addiction. Firat Med J 2004;9:50-53.

20. Siddiqui A, Ancha H, Tedesco D, Lightfood S, Stewart CA, Harty RF. Antioxidant Therapy with N-Acetylcysteine Plus Mesalamine Accelerates Mucosal Healing in aRodent Model of Colitis. Dig Dis Sci 2006;51:698705

21. Guijarro LG, Mate J, Gisbert JP, Perez-Calle JL, Marín-Jimenez I, Arriaza $\mathrm{E}$, et al. N-acetyl-L-cysteine combined with mesalamine in the treatment of ulcerative colitis: Randomized,placebo-controlled pilot study. World J Gastroenterol 2008;14:2851-2857.

22. Drapper H, Hadley M. Malondialdehyde determination as index of lipit peroxidation. Methods, Enzymol 1990;186:421.

23. Kurutas EB, Cetinkaya A, Bulbuloglu E, Kantarceken B. Effects of antioxidant therapy on leukocyte myeloperoxidase and $\mathrm{cu} / \mathrm{zn}$-superoxide dismutase and plasma malondialdehyde levels in experimental colitis. Mediators of Inflamm 2005:6;390-394

24. Grisham MB, Volkmer C, Tso P, Yamada T. Metabolism of trinitrobenzene sulfonic acid by the rat colon produces reactive oxygen species. Gastroenterology 1991;101:540-547.

25. Kuralay F, Yildiz C, Ozutemiz O. Effects of trimetazidine on acetic acid-induced colitis in female Swiss rats. J Toxicol Environ Health A 2003:66:169-179

26. Kruidenier L, Kuiper I, van Duijn W. Differential mucosal expression of three superoxide dismutase isoforms in inflammatory bowel disease. J Pathol 2003;201:7-16 